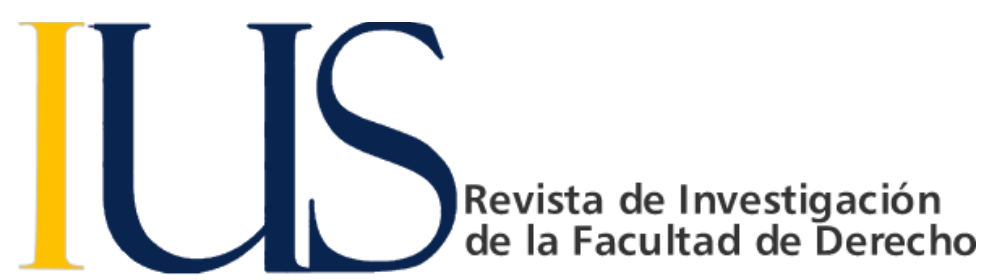

\title{
La cuantificación del lucro cesante en los procesos laborales de responsabilidad civil por despido inconstitucional. Casación Laboral 10956-2017-Tacna.
}

Giancarlo Delgado Pérez ${ }^{1}$

\begin{tabular}{ll}
\hline INFORMACIÓN DEL ARTÍCULO & RESUMEN \\
\hline Historia del artículo: & En la Casación Laboral 10956-2017-Tacna, la Corte Suprema establece un criterio para \\
Recibido el 04 de junio 2020 & la cuantificación del daño por lucro cesante que está lejos de representar una \\
Aceptado el 20 julio 2020 & valoración equitativa del resarcimiento pues, niega la incidencia de que el trabajador \\
& labore para otro empleador durante el periodo del despido. Esto es criticado por el \\
\hline Palabras clave: & autor, debido a que en el proceso, la Corte Suprema demuestra desconocimiento de \\
Trabajo & la regulación referente a la responsabilidad civil contractual al validar un monto \\
Daño & indemnizatorio por lucro cesante calculado sin tener en cuenta criterios establecidos \\
Lucro cesante & en el Código Civil, de aplicación supletoria a las relaciones laborales; incluso, tampoco \\
Responsabilidad civil contractual & tiene en cuenta criterios que razonablemente son aplicables en materia de la \\
Valoración equitativa & cuantificación del lucro cesante en la responsabilidad civil. \\
Criterios de cuantificación del daño &
\end{tabular}

The quantification of lost profits in civil liability labor processes for unconstitutional dismissal. Labor Cassation 10956-2017-Tacna.

\section{ABSTRACT}

\section{Keywords:}

Job

Damages

Loss of income

Contractual civil liability

Equitable assessment

Damage quantification criteria
In the Labor Cassation 10956-2017-Tacna, the Supreme Court establishes a criterion for the quantification of the damage for loss of income that is far from representing an equitable assessment of the compensation, because it denies the incidence that the employee works for another employer during the unemployment period. This is criticized by the author, because in this process, the Supreme Court demonstrate a lack of knowledge of the regulation according to contractual civil liability to validate a compensatory amount for loss of income calculated without taking into account criteria established in the Civil Code, which is applied in a supplementary way to labor relations; furthermore, it also does not take into account criteria that are reasonably applicable regarding to the quantification of lost profits in civil liability.

\section{Sumario}

Introducción. 1. Cuestiones preliminares. 2. Derecho al trabajo y deber de trabajar. 3. La responsabilidad civil en el proceso laboral. 3.1. La responsabilidad civil. 3.2. Elementos. 3.3. Funciones. 4. El daño indemnizable por lucro cesante. 5. El deber-carga de la víctima de mitigar

\footnotetext{
${ }^{1}$ Abogado por la Universidad Católica Santo Toribio de Mogrovejo, con estudios de maestría en Derecho con mención en Derecho Civil Empresarial en la Universidad Privada Antenor Orrego y actual maestrante del Master of Business Administration - MBA en la Universidad de Piura. Investigador independiente. Chiclayo, Perú. Email: delper91@gmail.com ORCID: https://orcid.org/0000-0002-3238-8455
} 
o evitar el daño. 6. Análisis de la Casación Laboral 10956-2017-Tacna. 7. Criterios o indicadores para establecer el quantum indemnizatorio por lucro cesante. 7.1. El lucro de la utilidad o ganancia neta y no los ingresos brutos. 7.2 Incidencia de la prestación de servicios subordinados e independientes durante el despido. 7.3. Periodos no imputables a las partes. 7.4. La carga de mitigación del daño. 7.5. Fórmula propuesta. Conclusiones. Bibliografía.

\section{Introducción}

Actualmente, los jueces laborales llevan a cabo procesos donde determinan la responsabilidad civil de los empleadores frente a sus trabajadores y establecen los montos indemnizatorios por los daños y perjuicios ocasionados a estos, como consecuencia de despidos inconstitucionales, incausados y fraudulentos que hayan sido previamente declarados judicialmente como tales. Práctica que ha sido reconocida desde hace casi veinte años, mediante el Pleno Jurisdiccional Laboral llevado a cabo en la ciudad de Tarapoto los días 5 al 8 de julio de 2000; sin mencionar que la propia Ley 26636 , Ley Procesal del Trabajo, publicada el 24 de junio de 1996, reconocía en su literal j) numeral 2 del artículo 4, la competencia de los juzgados de trabajo para conocer las pretensiones sobre indemnización por daños y perjuicios derivados del incumplimiento del contrato de trabajo.

La importancia de abordar el tema referente a la aplicación de la responsabilidad civil de los jueces laborales radica en que el tratamiento que vienen haciendo de esta institución jurídica es, muchas veces, errónea; pues, se analizan los elementos de la responsabilidad civil desde una perspectiva laboralista, olvidándose que es aquella institución jurídica (responsabilidad civil) la que se está aplicando en materias del derecho laboral, y no al revés. Analizar la responsabilidad civil desde una perspectiva netamente laboralista está generando que, específicamente, en relación al monto indemnizatorio por lucro cesante, se vengan aplicando criterios que están lejos de establecer una indemnización razonable y equitativa. Por el contrario, resultan ser montos indemnizatorios arbitrarios y que no tienen relación con la naturaleza de la institución del lucro cesante.

Tal es el caso de la Casación Laboral 10956-2017-Tacna de fecha 15 de enero de 2020, en donde los jueces de la Corte Suprema de Justicia de la República (en adelante, Corte Suprema), han negado la incidencia en el lucro cesante de haber laborado para otro empleador durante el periodo del cese como consecuencia del despido inconstitucional. Demostrando con ello, desconocimiento de la institución jurídica de la responsabilidad civil y, además, consolidando una práctica y aplicación equivocada del derecho, que ocasiona montos indemnizatorios que terminan generando enriquecimientos indebidos.

En consecuencia, se pretende proponer los criterios o indicadores que deberán seguir los operadores del derecho para establecer los montos indemnizatorios por lucro cesante en los procesos laborales de responsabilidad civil del empleador como consecuencia de un despido inconstitucional. Para lo cual, es necesario analizar el deber del trabajo o deber de trabajar, estudiar el desarrollo de la responsabilidad civil y sus elementos (particularmente el daño por lucro cesante) en los procesos laborales; $y$, finalmente, analizar la obligación de la víctima de evitar o mitigar el daño. Con lo anterior, lograremos proponer o establecer una fórmula que permita a los operadores del derecho acercarse a una cuantificación del daño por lucro cesante que represente una valoración equitativa del resarcimiento, en aplicación del artículo 1332 del Código Civil.

\section{CUESTIONES PRELIMINARES}

Mediante Casación Laboral 10956-2017-Tacna defecha 15 de enero de 2020, publicada en el diario oficial El Peruano el 20 de febrero de 2020, la Corte Suprema se ha pronunciado sobre la indemnización del daño causado por lucro cesante al trabajador que fue víctima de un despido inconstitucional, estableciendo en la sumilla de dicha casación que,

El hecho que el trabajador haya prestado servicios a otro empleador durante el periodo que se encontró despedido, no significa que no tenga derecho a reclamar indemnización por daños y perjuicios por lucro cesante, ya que de atender esta teoría, se estaría vulnerando el derecho del trabajador a conseguir ingresos propios para su subsistencia después del despido inconstitucional; por lo que, ello no debe servir para no otorgar o desmejorar el lucro cesante, ya que los ingresos adquiridos por el trabajador son el fruto del ejercicio de su derecho constitucional al trabajo.

Asimismo, la Corte Suprema estableció, erróneamente, en el penúltimo párrafo de su Fundamento Octavo que, Al respecto, se debe de entender que la obligación incumplida por el empleador se transforma en el deber de indemnizar el lucro cesante, puesto que ante un despido, como el que ha sufrido el demandante, se entiende que éste dejó de percibir las remuneraciones que normalmente venía percibiendo por la demandada, lo que determina un perjuicio 
económico, que se hace atendible; dejándose de lado el hecho que el actor haya prestado servicios o no a otro empleador, durante el periodo de desempleo, ya que de atender esta teoría, estaríamos vulnerando el derecho del actor a conseguir ingresos propios para su subsistencia después del despido inconstitucional; por lo que, ello no debe servir para desmejorar el lucro cesante, ya que los ingresos adquiridos por el actor son el fruto del ejercicio de su derecho constitucional al trabajo, ya que de hacerlo, caemos en el absurdo que la víctima se pague así mismo el lucro cesante, y llegar al extremo de exonerar al victimario del daño, a no pagar la indemnización, trastocando las funciones de la responsabilidad civil, mucho más que aquello significa desplazar la responsabilidad a un evento fuera de la relación jurídica sustantiva que la motivó.

Para entender la decisión de la Corte Suprema conviene revisar los antecedentes del proceso, donde se aprecia que la pretensión de la demanda se sustenta en la solicitud del pago de una indemnización por daños y perjuicios que comprendían el lucro cesante y el daño moral, como consecuencia del despido inconstitucional sufrido por la demandante.

En primera instancia, el Juez declaró fundada en parte la demanda y ordenó a la demandada cumplir con el pago de S/ 43,255.43 (cuarenta y tres mil doscientos cincuenta y cinco con $43 / 100$ soles) por el concepto de lucro cesante, el cual fue calculado tomando como base la última remuneración percibida por la demandante y el periodo dejado de laboral; $y$, además, ordenó el pago de S/ 3,000.00 (tres mil con 00/100 soles) por el concepto de daño moral; lo cual, fue confirmado en segunda instancia.

El problema gira en torno a la cuantificación del daño por lucro cesante y los criterios seguidos tanto por el juez de primera instancia y los jueces de segunda instancia, como los jueces de la Corte Suprema. Los jueces que vieron el proceso de la casación en mención establecieron el monto del lucro cesante solo teniendo en cuenta la última remuneración de la demandante y el tiempo dejado de laborar, dejándose de lado otros criterios indispensables para la cuantificación del daño; y, más aún, estableciendo que el hecho de que el demandante haya laborado para otro empleador durante el periodo del despido no puede ser tomado en cuenta para negar o desmejorar el monto por lucro cesante.

Con lo anterior, la Corte Suprema no ha tomado en cuenta la regulación de la responsabilidad civil contractual desarrollada en el Código Civil, que es de aplicación supletoria en el ámbito laboral; promoviendo así un criterio para establecer el monto del lucro cesante que está lejos de representar una valoración equitativa y razonable del resarcimiento.

\section{DERECHO AL TRABAJO Y DEBER DE TRABAJAR}

En materia laboral el Derecho al Trabajo ha sido desarrollado ampliamente en la jurisprudencia constitucional. Así también, el máximo intérprete de la Constitución, el Tribunal Constitucional, ha desarrollado en innumerable jurisprudencia el contenido constitucionalmente protegido del derecho al trabajo, el cual ha sido reconocido y regulado en el numeral 15 del artículo 2 y el artículo 22, ambos de la Constitución Política del Perú (en adelante, Constitución).

Respecto al desarrollo del Derecho al Trabajo realizado por el Tribunal Constitucional, en la STC 1647-2013PA/TC ha reconocido que "en virtud del derecho al trabajo, toda persona debe tener oportunidad de alcanzar una vida digna a través del desempeño de una actividad lícita libremente escogida" (fundamento 19); $y$, continúa precisando que, "a partir de ello, se deriva que el derecho al trabajo garantiza a las personas la posibilidad de obtener ingresos y hacer efectivo su proyecto de vida dedicándose a la profesión u oficio de su elección" (fundamento 20).

Por otro lado, respecto al contenido constitucionalmente protegido del derecho al trabajo, el Tribunal Constitucional, en la STC 1124-2001-AA/TC ha establecido que "el contenido esencial de este derecho constitucional implica dos aspectos. El de acceder a un puesto de trabajo, por una parte $y$, por otra, el derecho a no ser despedido sino por causa justa". Dualidad que sigue vigente hasta la actualidad; pues, hasta nuestros días el máximo intérprete de la Constitución sigue reconociendo este criterio con pronunciamientos recientes que, incluso, no solo reiteran la dualidad mencionada, sino que rechazan el intento de ingresar algún nuevo criterio o contenido del derecho al trabajo, como lo ha intentado ser el supuesto derecho a la estabilidad laboral absoluta, invocado a través del artículo 27 de la Constitución.

Estos pronunciamientos del Tribunal Constitucional han sido establecidos, principalmente, por el análisis y valoración del artículo 22 de la Constitución, el cual establece que "el trabajo es un deber y un derecho. Es base del bienestar social y un medio de la realización de la persona". Por lo que, es consecuente pensar que el desarrollo jurisprudencial de nuestro máximo intérprete de la Constitución es solo parcial; pues, aún no existe un desarrollo concienzudo del deber de trabajar, tal como lo establece y reconoce el propio 
artículo 22 antes citado. Lo cual, además, es evidenciado también en la jurisprudencia de la Corte Suprema, que ha centralizado la valoración y análisis del derecho al trabajo, dejando de lado la connotación obligacional (deber) del trabajo.

Es en este contexto en el que conviene prestar atención al deber de trabajar reconocido en el artículo 22 de nuestra Constitución; pues, la regulación establecida en la citada norma no es casual. Es ampliamente aceptado que el trabajo es también un deber de la persona, y así ha sido reconocido expresamente por varios países, además del nuestro, en sus respectivas constituciones. Por su parte, en el artículo 35 de la Constitución de España se establece que "todos los españoles tienen el deber de trabajar y el derecho al trabajo". Asimismo, el artículo 25 de la Constitución Política de Colombia reconoce que "el trabajo es un derecho y una obligación social y goza, en todas sus modalidades, de la especial protección del Estado". Por lo que, es innegable el reconocimiento constitucional de la dualidad del trabajo, como derecho y deber, ambos de rango constitucional.

Un texto importante y que ha marcado un precedente es la Encíclica Rerum Novarum (1891), del Papa León XIII dada el 15 de mayo de 1891, en la cual se realiza un análisis político, social y filosófico de la situación de la clase obrera de ese momento, estableciendo que,

Trabajar es ocuparse en hacer algo con el objeto de adquirir las cosas necesarias para los usos diversos de la vida y, sobre todo, para la propia conservación (...). Luego el trabajo implica por naturaleza estas dos a modo de notas: que sea personal, en cuanto la energía que opera es inherente a la persona y propia en absoluto del que la ejerce y para cuya utilidad le ha sido dada, y que sea necesario, por cuanto el fruto de su trabajo le es necesario al hombre para la defensa de su vida, defensa a que le obliga la naturaleza misma de las cosas, a que hay que plegarse por encima de todo. Pues bien: (...) hay que pensar de una manera muy distinta cuando, juntamente con el aspecto personal, se considera el necesario, separable solo conceptualmente del primero, pero no en la realidad. En efecto, conservarse en la vida es obligación común de todo individuo, y es criminoso incumplirla (número 32).

La cita anotada es clara y contundente. El trabajo no solo es un derecho, reconocido como tal por cuanto el trabajador utiliza su persona misma para conseguir el sustento para la vida; sino que, además de ello, es un deber impuesto por la propia naturaleza el buscar este sustento (trabajar), y la dualidad reconocida del trabajo no puede ser entendida en la realidad de manera separada; pues, conservarse y preservar la vida es una obligación inherente del ser humano, llegando a ser, incluso, un crimen incumplirla. Dualidad que ha sido reconocida en las cartas constitucionales de muchos países hasta la actualidad, tal como fue anotado en párrafos precedentes; $y$, de igual modo, nuestro Tribunal Constitucional ha recurrido a esa Encíclica para sustentar sus fallos, como en la STC 008-2005-PI/TC, en donde concluye, a partir de lo establecido por el Papa León XIII en 1891, que la importancia del trabajo descansa, entre otros dos aspectos, en el sustantivo, relativo a la esencialidad del acto humano, destinado al mantenimiento y desarrollo de la existencia y coexistencia sociales (fundamento 18).

En nuestra realidad legislativa, el deber de trabajar fue reconocido y establecido en el artículo 42 de la Constitución Política del Perú de 1979 y en el artículo 22 de nuestra actual Constitución. En este contexto, el deber de trabajar se presenta como la otra cara del derecho al trabajo. No obstante, el hecho de que una persona no trabaje o, simplemente, no quiera trabajar, no justifica que el Estado implemente sanciones, pues nuestro Estado no puede garantizar el derecho al trabajo de todos sus miembros (puestos de trabajo). Sin embargo, este deber se entiende como una obligación social o moral, que justifica la exigencia por parte del Estado a través de medios indirectos, como el recorte de ciertos beneficios o derechos (Blancas Bustamante, 2003, pp. 803-804). Por tanto, aun cuando el Estado no pueda garantizar el derecho al trabajo de todos sus miembros, sí existe el deber social y moral del trabajo, que justifica la existencia de medios indirectos que busquen la exigibilidad de este deber. Es decir, tal como lo precisa Jorge Toyama (2005)

"el deber de trabajo (...) viene a ser una obligación general a los ciudadanos sin una sanción concreta, es una suerte de llamada a la participación en el interés social, de lo que se trata es de vincular este deber al principio de solidaridad social" (p. 510).

Teniendo en cuenta lo anterior, y considerando el poco desarrollo doctrinario y jurisprudencial del deber de trabajar, es necesario reivindicar su relevancia ontológica y reconocer que el trabajo es, al igual que un derecho, un deber de la persona en relación consigo misma y en relación con la sociedad en donde vive; pues, de aquella depende su existencia y subsistencia misma, el funcionamiento ordinario, el bienestar y el progreso de la comunidad. Asimismo, tal como lo reconocen Manuel Barredo y Libardo Sarmiento (1997) al comentar el artículo 25 de la Constitución Política de Colombia, "los beneficios de la vida en sociedad exigen 
a cambio la contribución de la fuerza y la capacidad de trabajo de todos" (p. 92). Ello, debido a que, sin trabajar, las personas no podrían subsistir por sí mismas, y estarían trasladando esa carga (obligación), la de su supervivencia, a un tercero o al Estado. Teniendo en cuenta, además, que en la propia naturaleza del ser humano existe la obligación o mandato implícito de procurar mantener la existencia.

\section{LA RESPONSABILIDAD CIVIL EN EL PROCESO LABORAL}

Actualmente, los procesos de responsabilidad civil que se derivan de las relaciones laborales son conocidos o son de competencia de los jueces laborales. Sin embargo, existieron momentos en los que esta competencia no estaba del todo clara debido a las innumerables situaciones o contingencias con las que nos encontramos en las relaciones laborales; a tal punto que, estas incertidumbres, fueron motivo de Plenos Jurisdiccionales Nacionales y Plenos Jurisdiccionales Supremos, que se pronunciaban y presentaban conclusiones respecto a los diferentes casos laborales relacionados a la responsabilidad civil, donde se veía la competencia en materia de indemnizaciones por despidos, la cuantificación del daño moral, la cuantificación del lucro cesante, los daños punitivos, entre otros.

Pese a lo anterior, conviene revisar que ya desde la Ley 26636, Ley Procesal del Trabajo, se estableció en el literal j) numeral 2 del artículo 4 que,

Los Juzgados de Trabajo conocen de las pretensiones individuales o colectivas por conflictos jurídicos sobre: j) Indemnización por daños y perjuicios derivados de la comisión de la falta grave que causa perjuicio económico al empleador, incumplimiento del contrato y normas laborales cualquier fuera su naturaleza por parte de los trabajadores.

De igual modo, en la actual Ley 29497, Nueva Ley Procesal del Trabajo, se establece y reconoce en el literal b) numeral 1 del artículo 2 que,

Los juzgados especializados de trabajo conocen de los siguientes procesos: 1. En proceso ordinario laboral, todas las pretensiones relativas a la protección de derechos individuales, plurales o colectivos, originadas con ocasión de la prestación personal de servicios de naturaleza laboral, formativa o cooperativista, referidas a aspectos sustanciales o conexos, incluso previos o posteriores a la prestación efectiva de los servicios. Se consideran incluidas en dicha competencia, sin ser exclusivas, las pretensiones relacionadas a los siguientes: b) $L a$ responsabilidad por daño patrimonial o extra patrimonial, incurrida por cualquiera de las partes involucradas en la prestación personas de servicios, o terceros en cuyo favor se presta o prestó el servicio.

No obstante, tal como se ha mencionado en el primer párrafo de este apartado, a lo largo de los años, incluso durante la vigencia de las leyes antes acotadas, se han llevado a cabo Plenos Jurisdiccionales Nacionales y Plenos Jurisdiccionales Supremos, ambos en materia laboral, que han intentado marcar una pauta respecto de las incertidumbres que ocurrían en materia de responsabilidad civil dentro del proceso laboral. Tal como puede evidenciarse en los siguientes: Pleno Jurisdiccional Laboral llevado a cabo en la ciudad de Tarapoto los días 5 al 8 de julio de 2000, Pleno Jurisdiccional Nacional Laboral llevada a cabo en la ciudad de Lima los días 27 y 28 de junio de 2008, V Pleno Jurisdiccional Supremo en Materia Laboral y Previsional llevado a cabo en la ciudad de Lima el 19 de octubre de 2016 y el Pleno Jurisdiccional Laboral y Procesal Laboral llevado a cabo en la ciudad de Tacna los días 23 y 24 de mayo de 2019. Sin embargo, para este apartado analizaremos solo los dos primeros, reservando el análisis de los dos últimos para el apartado siguiente.

Siendo así, en el Pleno Jurisdiccional Laboral llevado a cabo en la ciudad de Tarapoto los días 5 al 8 de julio de 2000, los Jueces Superiores de diferentes Cortes Superiores de Justicia del país, acordaron como segundo punto que, "es competencia de los Jueces de Trabajo conocer y resolver las demandas de indemnización por daños y perjuicio originadas por el incumplimiento de las obligaciones derivadas del contrato de trabajo, o de normas legales o convencionales" (Pleno Jurisdiccional Laboral, 2000). Con lo cual, incluso antes de la vigencia de la actual Ley 29497 (publicada en el diario oficial El Peruano el 15 de enero de 2010) y durante la vigencia de la Ley 26636 (publicada en el diario oficial El Peruano el 24 de junio de 1996), los Jueces Superiores coincidieron en que la competencia respecto de los procesos de responsabilidad civil derivados de las relaciones laborales (contratos de trabajo) recaía en los jueces de trabajo.

Por su parte, en el Pleno Jurisdiccional Nacional Laboral llevada a cabo en la ciudad de Lima los días 27 y 28 de junio de 2008, los Jueces Superiores de diferentes Cortes Superiores de Justicia del país, debatieron sobre dos cuestiones importantes que tienen relación con la materia que nos ocupa en el presente artículo. Por un lado, estos jueces llegaron a la conclusión plenaria por mayoría que, "el Juez Laboral es competente para el conocimiento de las acciones de indemnización por 
daños y perjuicios derivados del contrato de trabajo" (Pleno Jurisdiccional Nacional Laboral, 2008). Reconfirmando la postura adoptada y acordada en el año 2000 desarrollado en el párrafo anterior. Por lo que, la competencia de los Jueces Laborales en materia de responsabilidad civil derivado de las relaciones laborales era reconfirmada.

Por otro lado, en este Pleno Jurisdiccional Nacional Laboral también se debatió respecto a si las remuneraciones dejadas de percibir con ocasión del despido de un trabajador repuesto mediante un proceso constitucional pueden ser reclamadas en sede laboral en un proceso de pago de indemnización por daños y perjuicios o en un proceso de pago de beneficios sociales. Ante lo cual, los Jueces Superiores que asistieron a este Pleno, acordaron por mayoría que, "las remuneraciones dejadas de percibir con ocasión del despido de un trabajador repuesto mediante un proceso de amparo, pueden ser reclamadas en uno de pago de beneficios sociales $y / o$ en un proceso de indemnización por daños y perjuicios" (Pleno Jurisdiccional Nacional Laboral, 2008). Ingresando con ello, incluso al esbozo de uno de los elementos de la responsabilidad civil, específicamente, el daño por lucro cesante.

En este escenario, es innegable que, en nuestra realidad procesal, los jueces laborales son los competentes para conocer de los procesos de responsabilidad civil del empleador como consecuencia de despidos inconstitucionales; es decir, procesos de indemnización por daños y perjuicios como consecuencia de la inejecución de las obligaciones generadas del contrato de trabajo. Esta última precisión, nos lleva también a revalidar el criterio según el cual, en las relaciones laborales surgidas del contrato de trabajo, lo que corresponde invocar es la responsabilidad civil contractual y no la extracontractual. Lo que no resulta innecesario reconocer, pues, incluso en la actualidad, aún es frecuente encontrar demandas laborales sobre indemnización por daños y perjuicios como consecuencia de un despido inconstitucional, incausado o fraudulento, donde los abogados de los demandantes invocan normas de la responsabilidad civil extracontractual para sustentar sus pretensiones.

Por lo que, se hace necesario ingresar brevemente al estudio de los elementos y las funciones de la responsabilidad civil; más aún, si tenemos en cuenta que el desarrollo de la responsabilidad civil en los procesos laborales a cargo (competencia) de los jueces laborales ha sido deficiente; pues, muchas veces parecen realizar el análisis de una responsabilidad civil ad hoc a las relaciones laborales, debido a los serios errores que comenten al momento de valorar y analizar los elementos constitutivos de la responsabilidad civil y los medios probatorios que ofrecen las partes procesales. Cuando en realidad, la responsabilidad civil, es una sola, sea que se traten de relaciones civiles, relaciones personales o relaciones laborales. Por lo que, la aplicación o intento de aplicación de los principios y garantías propios del Derecho Laboral (principio protector, principio in dubio pro operario, entre otros), normalmente, resultan erróneos; justamente, porque la institución jurídica en comento tiene una regulación especial; y, además, debido a que, respecto a este hecho, es la responsabilidad civil la que se aplica al ámbito laboral, y no al revés.

\subsection{La responsabilidad civil}

Dentro de la teoría de la responsabilidad civil existen dos tipos, la contractual y la extracontractual; las cuales, son reconocidas y reguladas en nuestro ordenamiento jurídico. En estricto, la responsabilidad civil es la disciplina que tiene como finalidad el resarcimiento del daño sufrido injustamente, ocasionado en la esfera jurídica de los particulares, como consecuencia del incumplimiento de una obligación voluntaria (responsabilidad civil contractual) o como resultado de una conducta dentro de un contexto donde no existe vínculo entre los sujetos (responsabilidad civil extracontractual). Por lo que, desde una perspectiva jurídica, según Leysser León (2017), la responsabilidad civil puede definirse como,

La situación del sujeto al que le toca experimentar, concretamente, las consecuencias, para él desventajosas, que una norma prevé y le impone atendiendo a la verificación de un determinado presupuesto. Dichas consecuencias desventajosas manifiestan la reacción del ordenamiento jurídico frente a un hecho que se considera reprobable, por atentar contra interés particulares o de la colectividad en general (pp. 144-145).

En ese contexto, es ampliamente reconocido, a nivel doctrinario y jurisprudencial, que la responsabilidad civil (tanto contractual como extracontractual) presenta una estructura común (elementos o presupuestos): Conducta Antijurídica, Daño, Relación de Causalidad y Factor de Atribución. Por lo que, corresponde analizar brevemente cada uno de estos elementos, a fin de entender y evidenciar los errores que se vienen cometiendo en la aplicación de esta institución jurídica en los procesos laborales.

Dentro del derecho laboral y, específicamente, en las relaciones laborales que unen al trabajador y su empleador, existe consenso entre doctrinarios y juzgadores, en que la responsabilidad civil que pudiera 
ocasionarse dentro de estas relaciones es contractual; pues, lo que une a estas partes es un contrato de trabajo; sobre el cual, sobra redundar respecto a su naturaleza contractual.

\subsection{Elementos}

Como se mencionó anteriormente, la responsabilidad civil, tanto contractual como extracontractual, presenta una estructura común (elementos o presupuestos): Conducta Antijurídica, Daño, Relación de Causalidad y Factor de Atribución. Por lo que, es necesario revisar brevemente cada uno de ellos; precisando, nuevamente, que no es finalidad de este trabajo realizar un desarrollo exhaustivo de los mismos.

Como primer presupuesto o elemento tenemos a la Antijuridicidad o Conducta Antijurídica, sobre la cual, el profesor Luis Legas y Lacambra (citado por Espinoza Espinoza, 2016) reconoce lo siguiente:

El concepto de ilicitud no debe ser confundido con el de legalidad. Esta última significa, en el sentido más amplio y general, existencia de leyes y sometimiento a las mismas de los actos de quienes les están sometidos. La licitud, en cambio, es la conformidad con los valores jurídicos, entre ellos y en primer orden, la justicia. Es por ello que existe una afinidad conceptual entre ilicitud y acto conforme al valor justicia (vale decir justo) (...). Entendida como la expresión unitaria e integrante de todos los valores de la convivencia, [que] presupone el valor trascendental de la persona humana $y$ representa, a su vez, el presupuesto de todo el orden jurídico. Por ello, la acepción material de ilicitud (conformidad al valor justicia) debe prevalecer a la acepción formal (conformidad al dato legislativo) (p. 114).

En ese sentido, en la responsabilidad civil contractual, este elemento está íntimamente relacionado con la "inejecución de las obligaciones" o su cumplimiento parcial, tardío o defectuoso; es decir, el elemento Conducta Antijurídico o llicitud serán valorados en relación con la obligación válidamente contraída que, supuestamente, se incumplió y fue la que ocasionó daños y perjuicios en la víctima.

Por su parte, el elemento o presupuesto Daño, es definido por el profesor Lizardo Taboada (2003) como "la lesión a todo derecho subjetivo, en el sentido de interés jurídicamente protegido del individuo en su vida de relación" (p. 34); o, como lo menciona Guido Alpa (2016), en resumidas cuentas, el daño es "la lesión a un interés protegido" (p. 780). Así también, no debe dejarse de lado que, dentro de la responsabilidad civil, el daño puede ser patrimonial o extra patrimonial; y, para el presente trabajo, importa el daño patrimonial, el cual está conformado por el daño emergente y lucro cesante.

Si bien es cierto, para los fines del presente trabajo solo importa el tipo de daño denominado "lucro cesante", conviene, mínimamente, conceptualizar o definir cada uno de estos tipos de daños patrimoniales. En este caso, el daño emergente es definido como "la pérdida que sobreviene en el patrimonio del sujeto afectado por el incumplimiento de un contrato o por haber sido perjudicado por un acto ilícito" (Espinoza Espinoza, 2016, pp. 300-301); o, dicho de otro modo, es la disminución patrimonial que experimenta la víctima. Por su parte, el lucro cesante es definido como "la ganancia patrimonial neta [énfasis agregado] dejada de percibir" (Massimo Bianca citado por Espinoza Espinoza, 2016, p. 301); es decir, por definición, el lucro cesante es la ganancia, la renta o la utilidad (todas ellas, netas) que la víctima deja de percibir.

Continuando con los elementos de la responsabilidad civil, en cuanto a la Relación de Causalidad o Nexo de Causalidad, Fernando de Trazegnies (1990) la definió como "la relación de causa - efecto, es decir, de antecedente - consecuencia entre la conducta antijurídica del autor y el daño causado a la víctima" (p. 83); y, para el caso de la responsabilidad civil contractual, según el artículo 1321 del Código Civil, entre la conducta antijurídica y el daño invocado debe existir una relación de causalidad inmediata y directa. Por lo tanto, que una consecuencia sea inmediata, hace referencia a la temporalidad del daño; motivo por el cual, el supuesto daño invocado debe ser inmediato en el tiempo y debe ocasionarse a continuación de la conducta antijurídica. Por otro lado, que sea consecuencia directa, hace referencia al hecho circunstancial; es decir, que el hecho o la omisión dolosa o culpable (conducta antijurídica) es la causa directa y necesaria del daño, cuando sin él (hecho antijurídico) este (el daño) no se habría producido; cuando el primero engendra al segundo y este no puede darse sin aquel.

Debemos destacar, además, que el Nexo de Causalidad es de mucha relevancia dentro del análisis en los procesos de indemnización por daños y perjuicios; pues, en la mayoría de casos se determina la no imputación de responsabilidad civil del supuesto victimario si se logra demostrar la fractura o ruptura del nexo causal; que, en el caso de la responsabilidad civil contractual, el Nexo de Causalidad se rompe cuando un caso fortuito o fuerza mayor impiden la ejecución de la obligación o determina su cumplimiento parcial, tardío o defectuoso, tal como lo regula el artículo 1314 de nuestro Código Civil. Asimismo, debe anotarse que, 
como será analizado más adelante, la carga de mitigación del daño actúa como una fractura del nexo de causalidad dentro de la responsabilidad civil.

Finalmente, el Factor de Atribución, desde la perspectiva de la responsabilidad civil contractual, es entendido como "el motivo o fundamento por el cual un sujeto debe responder ante el incumplimiento de una obligación que provocó un daño a otro" (Infante Caffi, s.f, p. 192). Elemento que es recogido en nuestro ordenamiento jurídico cuando establece que la imputación del deber de indemnizar se da a título de culpa leve, culpa inexcusable o dolo del responsable o victimario. Precisándose además que, existe una presunción legal iuris tantum de que el victimario (deudor de la indemnización) actuó con culpa leve; recayendo sobre la víctima (acreedor de la indemnización) la carga probatoria de la culpa inexcusable y dolo.

\subsection{Funciones}

En doctrina se ha desarrollado largamente lo relacionado a las funciones de la responsabilidad civil, analizando la capacidad de esta institución jurídica para normar la vida del hombre en sociedad y dotar de efectos jurídicos a aquellos actos del ser humano que repercuten negativamente en otra persona. En cuyo escenario, es necesario revisar las funciones de la responsabilidad civil más relevantes y aquellas que son reconocidas en nuestra realidad jurídica nacional; precisando, además, que estas muchas veces coinciden, pues no son excluyentes.

Dentro de la doctrina sobre la responsabilidad civil, se han reconocido las funciones tradicionales de esta institución jurídica: a) La de reaccionar contra el acto ilícito dañino, a fin de resarcir a los cuales se ha causado daño; b) La de retornar al status quo ante en el cual la víctima del daño se encontraba antes del perjuicio sufrido; c) La de reafirmar el poder punitivo del Estado; y, d) La de disuasión de las personas de la sociedad. Sin perjuicio de las cuales, la doctrina italiana ha considerado agregar dos nuevas funciones: e) $L a$ distribución de las pérdidas; y, f) La asignación de costos (Espinoza Espinoza, 2016).

En este trabajo, no se busca agotar o profundizar en el estudio doctrinario de la responsabilidad civil; por lo cual, una vez revisadas las funciones tradicionales y las nuevas funciones de esta, conviene revisar aquellas reconocidas en nuestra realidad jurídica. En donde encontramos que, dentro de la perspectiva micro sistémica, la responsabilidad civil tiene una triple función: satisfactoria, de equivalencia y distributiva; y, dentro de la perspectiva sistémica o macroeconómica, la responsabilidad civil tiene una doble función: preventiva y desincentivadora (Espinoza Espinoza, 2016).

Por lo tanto, las funciones de la responsabilidad civil pueden resumirse siguiendo este razonamiento: Con la indemnización por daños y perjuicios (responsabilidad civil) se busca satisfacer a la víctima, por lo que la reparación o resarcimiento deberá ser equivalente al daño ocasionado en ella; lo cual, originará una redistribución de los costos del daño; o, dicho de otro modo, la transferencia del daño. Todo esto, genera una actuación disuasiva o desincentivadora en la sociedad; pues, respecto del agresor, ha existido una sanción por el daño que ocasionó, que no es otra cosa que asumir los costos de la víctima.

\section{EL DAÑO INDEMNIZABLE POR LUCRO CESANTE}

Como se mencionó en el apartado referente a la responsabilidad civil en los procesos laborales, para este momento reservamos el análisis de dos Plenos Jurisdiccionales, pues estos hacen referencia directa no solo al daño por lucro cesante, sino también a su cuantificación. En ese contexto, en el $V$ Pleno Jurisdiccional Supremo en Materia Laboral y Previsional llevado a cabo en la ciudad de Lima el 19 de octubre de 2016, los Jueces Supremos integrantes de las Salas de Derecho Constitucional y Social de la Corte Suprema de Justicia de la República, trataron los temas relacionados a la indemnización y remuneraciones devengadas en los casos de despido fraudulento y despido incausado; dentro de los cuales, para los fines del presente artículo, se resalta lo relacionado al lucro cesante; respecto al cual, entre los fundamentos del acuerdo plenario, precisaron que,

La ausencia de pago de remuneraciones es un hecho evidente y por tanto un daño cierto, que podría ser calificado como lucro cesante, de manera que el monto de dichas remuneraciones pueda servir como un indicador [énfasis agregado] de cálculo del monto de la indemnización, además de otros conceptos y montos que el trabajador invoque como daños sufridos como consecuencia del despido (V Pleno Jurisdiccional Supremo en Materia Laboral y Previsional, 2016).

Con este fundamento, los Jueces Supremos reconocieron, y así lo precisaron, que el monto de las remuneraciones dejadas de percibir $\mathrm{o}$, dicho de otro modo, las remuneraciones no percibidas durante el periodo que duró el despido, son solo un indicador o criterio para establecer el monto indemnizatorio por lucro cesante, pues, existen otros criterios o indicadores que también son relevantes y tienen incidencia en el 
monto finalmente reconocido, sean estos positivos o negativos; es decir, que sumen el monto indemnizatorio o, también, lo resten o disminuyan.

El análisis del Pleno citado anteriormente encuentra respaldo, aunque con algunas precisiones 0 correcciones, en el Pleno Jurisdiccional Laboral y Procesal Laboral Ilevado a cabo en la ciudad de Tacna los días 23 y 24 de mayo de 2019; debido a que, los Jueces Superiores de diferentes Cortes Superiores de Justicia del país, debatieron sobre otros criterios o indicadores para el otorgamiento y la determinación del monto indemnizatorio por lucro cesante. En cuyo debate, acordaron por mayoría que,

En las pretensiones indemnizatorias derivadas de un despido inconstitucional, incausado o fraudulento declarado judicialmente como tales; el daño patrimonial invocado a título de lucro cesante, debe ser entendido como todos los ingresos dejados de percibir como consecuencia directa e inmediata del despido y no como las remuneraciones dejadas de percibir; y cuya existencia real y objetiva deberá ser acreditadas a fin de determinar la cuantificación que se sustentará en un parámetro temporal referido al tiempo de duración del cese; un parámetro cuantitativo referido al importe de los ingresos ciertos que hubiera dejado de percibir; y cualquier otra circunstancia que tuviera incidencia directa en dicha cuantificación; deduciéndose [énfasis agregado] los ingresosque hubiese obtenido el demandante por servicios realizados en dicho periodo de cese y los gastos que hubiera efectuado en el caso de continuar laborando, para la obtención de sus remuneraciones (Pleno Jurisdiccional Nacional Laboral y Procesal Laboral, 2019).

Si bien es cierto, los términos económicos utilizados por los Jueces Superiores no son del todo correctos, se debe reconocer que el sentido o fin del acuerdo es coherente con la institución jurídica de la responsabilidad civil y, específicamente, del elemento daño por lucro cesante; pues, en este acuerdo se reconoce que en este tipo de daño importa, no las remuneraciones dejadas de percibir, sino todos aquellos ingresos que el trabajador pudo percibir de continuar laborando para el empleador que lo despidió de forma inconstitucional, menos los costos (no gastos) de conseguir esos ingresos; restando, además, la incidencia de haber conseguido trabajo con un empleador distinto.

Revisados los plenos jurisdiccionales mencionados, conviene analizar detalladamente este tipo de daño; pues, es necesario entender lo que realmente significa el lucro cesante para que su resarcimiento sea correcto, coherente y equitativo. En este contexto, ingresemos a lo más básico del término, que no es otra cosa que su definición. Respecto a esto, el Diccionario de la Real Academia define a la palabra lucro, la cual proviene del latín lucrum (Del Col, 2007, p. 644), como la "ganancia o provecho que se saca de algo"; por lo que, en aplicación de esta definición, lucro cesante es la ganancia o provecho que se deja de obtener. Asimismo, este diccionario define la palabra ganancia como la "utilidad que resulta del trato, del comercio o de otra acción". Siendo esto así, llegamos a un punto en donde es necesario analizar, desde un punto de vista económico y/o contable, lo que estas palabras significan, solo así será posible entender la indemnización o resarcimiento del lucro cesante.

Agrega Donato Menéndez (1980) que, desde hace muchos años se puede evidenciar que se utilizan numerosos vocablos para expresar el resultado económico de una empresa o de la actividad humana. Dichas expresiones, unas más correctas y acertadas que otras, son las siguientes: beneficio, ganancia, ingresos netos, lucro, rédito, renta, realizado, realizar, superávit, utilidad (p. 1). Por tanto, es razonable establecer que, dentro del Código Civil, en la regulación referente al lucro cesante, se ha entendido la primera palabra (lucro), como "ganancia", "utilidad" o "ingresos netos". Lo cual, además, puede ser confirmado por la propia jurisprudencia y pronunciamiento (sentencia) que han emitido los juzgadores de nuestro Poder Judicial.

En la Casación Laboral 2996-2017, por ejemplo, que fue emitida el 27 de junio de 2019, la Corte Suprema estableció que, en cuanto al lucro cesante, "éste es una forma de daño patrimonial que consiste en la pérdida de una utilidad económica o ganancia [énfasis agregado] legítima por parte de la víctima como consecuencia del daño y que se habría dado de no haber sucedido el evento dañoso" (Fundamento Noveno). Asimismo, en la Casación 7589-2014 de fecha 5 de noviembre de 2015, se estableció que, "el lucro cesante es una forma de daño patrimonial y viene a ser las ganancias [énfasis agregado] o expectativas legítimas que se ven frustradas" (Fundamento Décimo). Por tanto, queda reafirmado lo que fue establecido en el párrafo anterior; lo cual, es importante resaltar debido a que no es lo mismo hablar de ingresos totales (entendido como ingresos brutos), que hablar de "ingresos netos", a los cuales se les ha restado la incidencia de los costos incurridos para conseguir los ingresos brutos.

Por lo tanto, el lucro cesante, como una creación jurídica que incluso encuentra sustento en las perspectivas económicas y contables, se refiere a la ganancia, utilidad o ingresos netos que deja de percibir 
la víctima como consecuencia del acto antijurídico ejecutado por el victimario. En cuyo caso, por definición, sería erróneo pensar, y más aún, establecer que el lucro cesante incluye todos los ingresos que la víctima pudo haber obtenido sin la incidencia de ningún costo; pues, es conocido y aceptado que toda actividad económica genera un costo, en el cual se incurre, justamente, para obtener los beneficios o ganancias que se buscan a través de dicha actividad. Este costo, mínimamente, es conocido como el costo de oportunidad; definido como el "coste de la inversión de los recursos disponibles, en una oportunidad económica, a costa de la mejor inversión alternativa disponible" (Academia de Inversión, 2016); dicho de otro modo, el costo de oportunidad de una decisión económica o actividad económica es el conjunto de cosas que se sacrifican por asignar un recurso escaso (tiempo, dinero, recursos naturales, etc.) a cierto objetivo y no a otro alternativo, con la finalidad de obtener un beneficio mayor (Arim, 2012).

En consecuencia, aplicando estos últimos razonamientos al ámbito laboral, como lo refiere Leysser León Hilario, citado por Carlos Quispe Montesinos (2019),

Lucro, como es evidente, no equivale a ingreso. El lucro es el ingreso menos los gastos. Los gastos a los que nos referimos son aquellos que se requiere abonar, precisamente, para mantener la fuente del ingreso y para producir el ingreso. Lucro es sinónimo de rédito o utilidad. Si se resarce con el ingreso, se incurre en el error de considerar que dicho ingreso se produce inevitablemente para el damnificado, sin necesidad de que este contribuya a generarlo (mediante su trabajo, por ejemplo)" (p. 131).

Lo que implica, justamente, que en materia de responsabilidad civil en el ámbito laboral (por despido inconstitucional), el lucro cesante no puede ser equiparado a los ingresos brutos que percibiría el trabajador en el supuesto de que la relación laboral seguiría vigente; sino, el lucro cesante en realidad expresa aquella utilidad o ganancia (neta) que el trabajador deja de percibir; lo cual, como ya se expresó, no es lo mismo. Por lo que, el lucro cesante no puede ser entendido como las remuneraciones y todo ingreso dejado de percibir por el trabajador, "toda vez que constituiría enriquecimiento indebido" (Casación Laboral 7625-2016-Callao, fundamento noveno).

\section{EL DEBER-CARGA DE LA VÍCTIMA DE} MITIGAR O EVITAR EL DAÑO

Existe divergencia en cuanto al origen de la mitigación del daño, pero ya era posible encontrar una clara referencia en el Digesto de Justiniano (Ugarte Mostajo, 2018, p. 121). No obstante, se debe precisar que lo importante de la mitigación del daño es su naturaleza jurídica; pues, a pesar de que en parte de la doctrina y la jurisprudencia ha sido concebido como un "deber" u "obligación" de la víctima, lo cierto es que, no reúnelas características para ser tal (Pérez Velázquez, 2015, p. 21), porque un "deber", en sentido técnico, constituye una situación jurídica subjetiva pasiva que impone a su titular un comportamiento orientado a satisfacer un interés ajeno, lo que no sucede en el supuesto "deber de mitigar el daño", debido a que su ejercicio no está destinado a satisfacer el derecho subjetivo de un tercero. Por estas razones, la mitigación del daño es más una carga que recae sobre la víctima del daño (acreedor de la indemnización) como consecuencia del incumplimiento de la obligación contraída. Carga que es entendida como la situación jurídica de aquella persona que debe efectuar determinado comportamiento (activo u omisivo) si quiere tener la posibilidad de utilizar alguna situación activa suya, porque las normas subordinan dicha posibilidad a la condición de que él realice tal comportamiento (Ugarte Mostajo, 2018, pp. 129-130). Precisando, además, que el término "mitigar" no es del todo correcto, pues resulta insuficiente; ello, debido a que a la víctima le corresponde no solo "mitigar" o reducir el daño, sino también procurar evitar que se produzca (Pérez Velázquez, 2015, p. 22).

En ese contexto, la carga que tiene la víctima de evitar el daño o, mínimamente, mitigarlo, ha sido reconocido dentro de la regulación referente a la responsabilidad por inejecución de obligaciones (responsabilidad civil contractual); específicamente, en el artículo 1327 del Código Civil, según el cual, "el resarcimiento no se debe por los daños que el acreedor habría podido evitar usando la diligencia ordinaria, salvo pacto en contrario". En ese sentido, es reconocido legalmente que la víctima del daño o supuesto acreedor del resarcimiento tiene la carga de evitar el daño, dentro de un contexto de diligencia ordinaria; o, mínimamente, tiene la carga de mitigar los efectos del daño; de lo contrario, su conducta podrá ser imputada para reducir el monto del resarcimiento.

En cuanto a esto, debemos tener en cuenta la regulación referente a las relaciones contractuales; pues, dentro de estas relaciones, el artículo 1362 del Código Civil, reconoce y establece que "Ios contratos deben negociarse, celebrarse y ejecutarse según las reglas de la buena fe y común intención de las partes". Es decir, en materia contractual (incluida la relación contractual laboral) se exige una conducta dentro de los términos de la buena fe; lo cual significa que, incluso cuando una de las partes causara un perjuicio a la otra, 
esta tiene la carga de mitigar el daño. Lo cual, además, es coherente y razonable, debido a que la víctima debe procurar evitar que los efectos de la conducta ilícita le resulten más gravosos. En ese mismo sentido, y tal como lo reconoce Guido Alpa (2016), citando a Calabresi y Hischoff, "el causante del daño debe asumir siempre, de manera inicial, el daño provocado a terceros, pudiendo luego transferirlo sobre estos, solo si se determina que los terceros habrían podido prevenir el daño de manera menos costosa [énfasis agregado]" (p. 222).

Para graficar y apreciar lo desarrollado en el párrafo anterior, resulta conveniente apoyarnos en el ejemplo al que recurre Marco Ortega Piana (2015):

$A B C$ es una empresa de logística que se compromete con XYZ a transportar y depositar en los almacenes de esta última 10,000 equipos de sonido. Al realizar la descarga de la mercadería en los almacenes de XYZ, uno de los camiones de $A B C$ golpea una pared de dicho almacén ocasionando un derrumbe que afecta a 300 unidades descargadas, las mismas que quedan destruidas. Sin embargo, XYZ permite y requiere que el total de la mercadería sea depositada en lo que quedaba de los almacenes, sin tomar medidas adicionales de cuidado con relación a la afectación estructural del almacén. Por último, al día siguiente se produce el derrumbe total del local, por lo que, se pierden las 9,700 unidades restantes (p. 276).

En virtud de la carga de mitigación del daño, dentro del ejemplo acotado, la empresa ABC solo respondería por la afectación parcial del almacén y por la destrucción de los 300 equipos de sonido (no por el total de 10,000 unidades). En cuyo caso, la empresa $A B C$ no tendrá obligación de resarcir los daños ocasionados con posterioridad al accidente; pues, sobreviene el deber de la empresa XYZ de procurar todos los actos necesarios para mitigar los daños directos o mitigar los daños potenciales. Por lo cual, se puede decir que la empresa $\mathrm{XYZ}$ ha incumplido con la carga de mitigación del daño, lo que deriva en una fractura del nexo causal y, con ello, el daño ocasionado como consecuencia de la negligencia de la empresa XYZ no será imputable a la empresa $A B C$.

Como ya se ha mencionado en párrafos anteriores, esta carga es una manifestación o expresión concreta del principio de buena fe en materia contractual; porque, sin duda, no es posible admitir la inacción o inercia del acreedor afectado (víctima), que se limita a ver crecer sus propios daños con el convencimiento de que todas las consecuencias y secuelas que se desprendan del incumplimiento de la obligación contractual serán íntegramente reparadas por el deudor del resarcimiento (victimario) (Ortega Piana, 2015, pp. 276278). En consecuencia, es el principio de buena fe contractual el que impone la carga de tomar todas las medidas necesarias y razonables para mitigar o reducir los efectos dañosos del incumplimiento e, incluso, para evitarlo, con la finalidad de que los daños no se extiendan de manera innecesaria.

Además de ser una manifestación del principio de buena fe contractual, no se debe perder de vista que la responsabilidad civil (contractual o extracontractual) tiene límites; pues, tal como muchos autores lo han reconocido, incluso la misma jurisprudencia así lo ha establecido, no todos los daños son indemnizables. Por lo que, en palabras de Guido Alpa (2016), se habla de límites al resarcimiento, lo cuales son: "el nexo causal, la intervención de tercero, el deber [carga] de mitigar el daño [énfasis agregado], la concurrencia de culpa del damnificado y la irrelevancia económica del daño" ( $p$. 791). Por lo tanto, la mitigación del daño como una carga de la víctima del mismo, actúa no solo como una manifestación del principio de buena fe contractual; sino, sobre todo, como un límite de la responsabilidad civil o, dicho de otro modo, como un límite de la cuantificación de la indemnización; pues, esta mitigación del daño significará, en definitiva, un criterio para exonerar al victimario del pago del resarcimiento o, mínimamente, para reducirlo (Guido Alpa, 2016, p. 804), debido a que la indemnización o resarcimiento no puede implicar un enriquecimiento del damnificado.

\section{ANÁLISIS DE LA CASACIÓN LABORAL 10956- 2017-TACNA}

Como ya se ha mencionado en los dos primeros apartados del presente trabajo, este pronunciamiento de la Corte Suprema es actual; la Casación ha sido emitida el 15 de enero de 2020 y publicada en el diario oficial El Peruano el 20 de febrero de 2020, y abarca, principalmente, lo relacionado a la determinación del quantum indemnizatorio por lucro cesante, como consecuencia de un despido inconstitucional. Dentro de esta Casación cobran relevancia algunos de sus considerandos; los cuales, pese a ser coherentes con lo que se ha venido desarrollando en esta investigación, son utilizados para tomar una decisión que se aparta de la regulación y naturaleza del lucro cesante que previamente se reconoce y establece.

En el Considerando Sexto de la Casación en comento, la Corte Suprema analizó los alcances del lucro cesante y estableció al respecto lo siguiente:

Es un tipo de daño patrimonial que hace referencia al lucro [énfasis agregado], al dinero, a la ganancia [énfasis agregado], a la renta que una 
persona deja de percibir como consecuencia del perjuicio o el daño que se le ha causado, es decir, el monto económico dejado de percibir; pues si no se hubiese originado el daño, el sujeto seguiría percibiendo el dinero que le corresponde.

Según el jurista Espinoza Espinoza señala que se manifiesta por el no incremento en el patrimonio del sujeto que ha sufrido el daño (sea por el incumplimiento de un contrato o por un acto ilícito. Es la ganancia patrimonial neta dejada de percibir [énfasis agregado] por la víctima.

En cuanto al daño lucro cesante, hace referencia al lucro, al dinero, a la ganancia [énfasis agregado], a la renta neta [énfasis agregado] que una persona deja de percibir como consecuencia del perjuicio o daño quese le ha causado; si una persona no hubiera sufrido de un daño o perjuicio, hubiera seguido lucrando sin problemas, lucro que se pierde, que cesa por culpa del daño o del perjuicio.

En este considerando la Corte Suprema reconoce y establece que el lucro cesante no es todo ingreso que deja de percibir la persona o trabajador; sino, por el contrato, el lucro cesante es la utilidad, ganancia o renta, todas ellas netas, que se dejan de percibir como consecuencia del evento dañoso. Como se dijo anteriormente, esto es coherente con lo que ha sido analizado en el presente trabajo; pues, se ha reconocido que toda actividad económica genera un costo, en el cual se incurre, justamente, para obtener los beneficios o ganancias que se buscan a través de dicha actividad. Pese a lo anterior, en el Considerando Octavo de la Casación en comento, la Corte Suprema dejó de lado lo precisado en la premisa del Considerando Sexto y reconoció un monto indemnizatorio que contemplaba todos los ingresos (brutos) del demandante (trabajador), sin tener en cuenta lo que ella misma definió como lucro cesante; amparándose, incluso, en lo dispuesto por el artículo 1332 del Código Civil, según el cual, "si el resarcimiento del daño no pudiera ser probado en su monto preciso, deberá fijarlo el juez con valoración equitativa". Así, en el sexto y sétimo párrafo del considerando bajo comentario, estableció lo siguiente:

Al respecto, se debe de entender que la obligación incumplida por el empleador se transforma en el deber legal de indemnizar el lucro cesante, puesto que ante un despido, como el que ha sufrido el demandante, se entiende que este dejó de percibir las remuneraciones que normalmente venía percibiendo por la demandada, lo que determina un perjuicio económico, que se hace atendible; dejándose de lado el hecho que el actor haya prestado servicios o no a otro empleador [énfasis agregado], durante el periodo de desempleo, ya que de atender esta teoría, estaríamos vulnerando el derecho del actor a conseguir ingresos propios para su subsistencia después del despido inconstitucional; por lo que, ello no debe servir para desmejorar el lucro cesante, ya que los ingresos adquiridos por el actor son el fruto del ejercicio de su derecho constitucional al trabajo, ya que de hacerlo, caemos en el absurdo que la víctima se pague así mismo el lucro cesante, y llegar al extremo de exonerar al victimario del daño, a no pagar la indemnización, trastocando las funciones de la responsabilidad civil, mucho más que aquello significa desplazar la responsabilidad a un evento fuera de la relación jurídica sustantiva que la motivó.

Siendo así, determinándose un perjuicio económico al actor, de acuerdo a lo señalado en los párrafos precedentes, se hace atendible el lucro cesante pretendido por el actor; pero teniendo en cuenta que en el caso concreto, el resarcimiento del daño no poder ser probado en su monto preciso, se concediera que este debe otorgarse en aplicación del artículo 1332 del Código Civil, conforme lo realizó el colegiado superior, tomándose como referencia y/o parámetro para ello, la última remuneración percibida por la demandante, así como el periodo dejado de laboral [énfasis agregado]. Precisándose que el monto reconocido a favor del demandante, no equivale a remuneraciones devengadas, sino a la valorización equitativa conforme lo faculta el artículo 1332 del Código Civil, pero teniendo solo como referencia la última remuneración.

Con la finalidad de comprender la crítica y el análisis de la Casación bajo comentario, conviene fragmentar la cita en determinadas partes. En ese sentido, es cierto que la obligación incumplida por el empleador (demandando) se convierte en la obligación legal de indemnizar los daños y perjuicios ocasionados; pues, ante un despido inconstitucional, el trabajador (demandante) ha permito la fuente de sus ingresos, que se traducía en las remuneraciones que percibía como contraprestación por su trabajo. Sin embargo, la Corte Suprema yerra al establecer que, para el cálculo del lucro cesante, debe dejarse de lado el hecho de que el demandante haya prestado labor efectiva para otro empleador, debido a que, según la Corte Suprema, los ingresos generados por el demandante son fruto del ejercicio legítimo de su derecho constitucional al trabajo; error que se genera porque se ha buscado dotar de una perspectiva laboral a una institución que es netamente civil. 
Como lo hemos visto anteriormente, el error antes anotado puede ser evidenciado desde dos aristas que, finalmente, convergen. Por un lado, olvidar completamente que el trabajo, reconocido constitucionalmente, no solo es un derecho, sino también un deber de todo ciudadano, el cual viene dado por su condición de persona; por otro lado, no tener en cuenta que dentro de la responsabilidad civil existe la carga de mitigar o evitar el daño, el cual recae sobre la víctima. Por lo que, analizadas en conjunto estas dos aristas, podemos reconocer que el hecho de haber prestado labor efectiva para otro empleador $y$, consecuentemente, haber recibido una remuneración (ingresos brutos), repercute en la cuantificación del lucro cesante, porque la víctima ha logrado, consciente o inconscientemente, mitigar el daño que se le venía causando, en pleno ejercicio no solo de su derecho, sino también de su deber de trabajar; más aún, si tenemos en cuenta que esos ingresos no habrían podido ser percibidos si el demandante seguía prestando labor efectiva a su empleador demandado.

La Corte Suprema, además, establece que con el reconocimiento de la incidencia (negativa) de la prestación de servicios a otro empleador en el cálculo del lucro cesante, se incurriría en un supuesto absurdo, donde la víctima se pague a sí misma el daño y se exonere al victimario; también, añadeque supuestamente se llegarían a trastocar las funciones de la responsabilidad civil; lo cual, nos remite, nuevamente, a la carga de mitigación del daño, que recae sobre la víctima. Con ello, la Corte Suprema deja de lado esta carga reconocida por nuestro ordenamiento jurídico en el artículo 1327 del Código Civil; más aún, si tenemos en cuenta que, en el presente caso, la víctima, en efecto, evitó parte de los daños debido a que procuró sus ingresos a través de otra fuente, lo que no habría sido posible si mantenía su vínculo laboral con su empleador demandado. Por lo tanto, reducir el monto del lucro cesante en proporción a los ingresos percibidos por el demandante por la prestación de sus servicios a otro empleador durante el periodo del despido, no significa que la víctima se pague a sí misma el daño y se exonere al victimario; sino, por el contrario, esto significa que la víctima ha mitigado el daño que se le venía causando, en aplicación de la carga reconocida en el artículo 1327 del Código Civil y en pleno ejercicio de su deber constitucional de trabajar. Por otro lado, en el último párrafo (párrafo sétimo) del Considerando Octavo, la Corte Suprema se ampara en lo regulado en el artículo 1332 del Código Civil para establecer el quantum indemnizatorio por lucro cesante teniendo en cuenta la última remuneración percibida por el demandante y el tiempo de duración del despido, la cual concluyó con la reposición efectiva del trabajador. Lo curioso, es que a continuación, la Corte Suprema, precisa que el monto reconocido no equivale a las remuneraciones devengadas, sino a una valoración equitativa. Sin embargo, en la práctica, el monto establecido como indemnización por lucro cesante es, en efecto, equivalente a las remuneraciones que el demandante habría seguido percibiendo de no materializarse el despido inconstitucional, las cuales fueron proyectadas teniendo solo en consideración la última remuneración (bruta) percibida por el trabajador. Es decir, la Corte Suprema ha reducido el cálculo del lucro cesante a la aplicación de una fórmula que es, en demasía, simple: $L C=U R \times M D L$. Donde $L C$ es el lucro cesante, UR es la última remuneración y MDL son los meses dejados de laboral durante el despido y hasta la reposición efectiva. Por lo tanto, aquella resulta ser una fórmula inaplicable a los diferentes casos de indemnización por daños y perjuicios en materia de relaciones laborales.

Con este criterio, simplista y reducido, los jueces de la Segunda Sala de Derecho Constitucional y Social Transitoria de la Corte Suprema van contra uno de los criterios reconocidos hace poco menos de un año, en el Pleno Jurisdiccional Laboral y Procesal Laboral llevado a cabo en la ciudad de Tacna los días 23 y 24 de mayo de 2019 y contra el V Pleno Jurisdiccional Supremo en Materia Laboral y Previsional llevado a cabo en la ciudad de Lima el 19 de octubre de 2016, donde se estableció que las remuneraciones percibidas por el demandante (víctima) y el periodo que duró el despido eran solo uno de los criterios para fijar el monto indemnizatorio por lucro cesante; precisándose también en el Pleno del año 2019 llevado a cabo en Tacna, que en este tipo de daño importa, no las remuneraciones dejadas de percibir, sino todos aquellos ingresos que el trabajador pudo percibir de continuar laborando para el empleador que lo despidió de forma inconstitucional, menos los costos (no gastos) de conseguir esos ingresos; restando, además, la incidencia de haber conseguido trabajo con un nuevo empleador.

Asimismo, en cuanto al análisis de esta Casación, conviene reiterar que, se han resaltado algunos fundamentos que sirvieron como sustento para la decisión final adoptada. En las cuales, tal como ha sido expuesto en los párrafos precedentes, hemos caído en cuenta que las premisas de las que parte la Corte Suprema son ciertas o válidas; sin embargo, la inferencia o conclusión a la que arriba no lo es, incurriendo así, en un vicio de motivación interna; en virtud del cual, para nuestro Tribunal Constitucional, "la falta de motivación interna del razonamiento (defectos internos de la motivación) se presenta en una doble 
dimensión; por un lado, cuando existe invalidez de una inferencia a partir de las premisas que establece previamente el juez en su decisión; y, por otro lado, cuando existe incoherencia narrativa" (STC 728-2008$\mathrm{PHC} / \mathrm{TC}$, fundamento 7 literal c); específicamente, en su primera dimensión. Ello sucede porque la Corte Suprema estableció que el lucro cesante es la utilidad o renta neta que se deja de percibir como consecuencia del evento dañoso; pero, al concluir y analizar el caso concreto, reconoce tan solo los ingresos brutos y no la renta neta que debió percibir el demandante, aplicando una fórmula en la que no se evidencia la resta obvia que significa hallar la utilidad de una actividad económica:

Utilidad = Ingresos - gastos.

Por lo antes expuesto, el monto que reconoce la Corte Suprema como lucro cesante está lejos de representar una cuantificación equitativa y razonable; pues, ha dejado de lado lo más básico del significado de este tipo de daño: utilidad o renta neta. Además de lo cual, la Corte Suprema ha negado la incidencia de que la víctima haya obtenido ingresos mensuales a través de otro empleador, los cuales no habría podido obtener de no haberse configurado el hecho dañoso; con lo que, la víctima ha actuado de acuerdo a la carga de mitigación del daño. Esto significa, contrariamente a lo reconocido por la Corte Suprema, que se ha establecido un monto indemnizatorio por lucro cesante que es irrazonable y arbitrario, y desconoce los criterios establecidos por nuestro ordenamiento jurídico en materia de responsabilidad civil contractual, detallados en el Código Civil. Por lo tanto, la fórmula establecida por la Corte Suprema, debe rechazarse, por no ser coherente con la institución jurídica de la responsabilidad civil y, específicamente, con el lucro cesante como un tipo de daño indemnizable

\section{CRITERIOS O INDICADORES PARA ESTABLECER EL QUANTUM INDEMNIZATORIO POR LUCRO CESANTE}

Pese a que existe jurisprudencia del Poder Judicial, a través de las diferentes instancias, que se acercan a la esencia del lucro cesante, vemos que con el último pronunciamiento se empieza nuevamente a alejar del verdadero concepto y naturaleza del lucro cesante como un daño resarcible a través de un proceso de responsabilidad civil. Actualmente vemos que el análisis del elemento "daño" $y$, particularmente, del lucro cesante, se ha reducido a una simple fórmula matemática que multiplica el número de meses entre el despido y la reposición efectiva, por la última remuneración percibida por el demandante (víctima). Con lo cual, en la práctica, a pesar de que sea negado por los jueces, estos terminan reconociendo las remuneraciones devengadas proyectadas del demandante, aunque invoquen el artículo 1332 del Código Civil para una supuesta valoración equitativa del lucro cesante. Por lo que, a raíz de lo estudiado y analizado precedentemente, resulta necesario aportar en la valoración de este tipo de daño estableciendo los criterios a tomar en cuenta y proponiendo una fórmula que, en efecto, signifique una correcta, razonable y equitativa determinación o cuantificación del lucro cesante.

\subsection{El lucro es la utilidad o ganancia neta y no los ingresos brutos}

Ya hemos profundizado en el análisis del lucro cesante como una institución jurídica que tiene sustento en la perspectiva económica y contable, el cual representa las ganancias netas dejadas de percibir como consecuencia del evento dañoso (incumplimiento de obligaciones). Asimismo, se ha precisado que las remuneraciones y el tiempo que dura el despido son tan solo uno de los criterios o indicadores para determinar el monto de la indemnización. Por tanto, en materia laboral y procesos de indemnización por despidos inconstitucionales, uno de los indicadores para la determinación del daño no será el de las remuneraciones brutas (ingresos brutos) que deja de percibir el demandante (víctima), sino tan solo sus retribuciones netas, debido a que el lucro cesante no es equivalente a la totalidad de ingresos, sino solo el margen de ganancia que se deja de percibir. En cuyo caso, es indispensable tener en cuenta la generación de ingresos derivados del trabajo y de toda actividad económica requiere de ciertos costos en los que incurre el propio prestados de servicios o trabajador (Quispe Montesinos, 2019, pp. 133-134). Por ejemplo, los costos del transporte para llegar al lugar de trabajo, la adquisición de bienes para prestar el servicio, la alimentación dentro de la jornada de trabajo, etc.; pues, quien ha sido despedido, lógicamente, deja de incurrir en estos costos.

Es razonable reconocer y pensar que la determinación de los costos en los que incurre una persona para generar su remuneración es sumamente difícil. Sin embargo, no es una tarea imposible si nos remitimos a información estadística confiable, que nos podría aproximar verdaderamente a una cuantificación o valoración equitativa del resarcimiento. Estas bases de datos nos proporcionan información promedio de la población peruana. Dentro de esta información, será necesario identificar qué es lo que interesa para el tema de análisis. En cuyo caso, uno de los datos más relevantes será el ingreso promedio (bruto) de una 
persona que vive en la ciudad o en un espacio geográfico similar al lugar donde se realiza el proceso. Por el lado opuesto, para determinar los costos que hemos aludido anteriormente, es necesario usar aquellos datos que nos informen sobre los gastos promedios en transporte y alimentación fuera del hogar en los que incurre una persona que vive en la ciudad o en un espacio geográfico similar al lugar donde se realiza el proceso. Estos últimos datos, han sido tomados en cuenta porque es la información que nos brindan las bases de datos y son los más cercanos a reflejar los costos directos en los que incurriría una persona promedio para generar sus ingresos mensuales.

En ese sentido, cobra importancia recurrir al Instituto Nacional de Estadística e Informática (en adelante INEI) que, en su Informe Técnico, presentó la Evolución de la Pobreza Monetaria (2019) en el Perú durante los años 2007 al 2018. En este informe técnico se puede evidenciar que el ingreso real promedio per cápita mensual en el ámbito geográfico urbano del Perú en el año 2018 es de S/ 1,028.00 (mil veintiocho con 00/100 soles) (p. 117); y, además, se precisa que el gasto real promedio per cápita mensual en el ámbito geográfico urbano del Perú en el año 2018 por transporte es de S/ 61.00 (sesenta y uno con 00/100 soles) (pp.103-104) y por alimentos consumidos fuera del hogar es de $S$ / 108.00 (ciento ocho con 00/100 soles) (pp.103-104), los que sumados hacen el monto de S/ 169.00 (ciento sesenta y nueve con 00/100 soles). En consecuencia, podemos apreciar que los costos directos (gastos) promedios mensuales en los que, razonable $y$ presumiblemente, incurre una persona de la zona urbana para generar sus ingresos, representan el $16.44 \%$, justamente, de esos ingresos promedios mensuales. Un porcentaje casi idéntico obtenemos si revisamos los datos nacionales para la zona rural. Por lo tanto, es razonable concluir que, una persona promedio tiene como ganancias netas o utilidades el $83.56 \%$ de sus ingresos brutos. Cifra que podría ser redondeada al $84 \%$, con la finalidad de facilitar cualquier cálculo que a partir de este dato se vaya a realizar. Teniendo en consideración, además, que es razonable considerar que, mientras más altos sean estos, sus costos serán proporcionales y también serán más altos.

Este es un modo equitativo y razonable de determinar cuál es la retribución neta que obtiene un trabajador (persona promedio en nuestro país) por la prestación de sus servicios a un empleador. Dato que debe ser tomado en cuenta para establecer uno de los criterios o indicadores que aportarán para la determinar la indemnización por lucro cesante. Por lo que, si una persona tiene una remuneración (conceptos remunerativos) bruta de $S / 2,500.00$ (dos mil quinientos con $00 / 100$ soles), la utilidad promedio o ganancia neta promedio que obtiene es de $S / 2,100$ (dos mil cien con 00/100 soles). Como se mencionó, se busca llegar a una valoración equitativa y que respete el concepto y naturaleza del lucro cesante como un tipo de daño. Finalmente, debiéndose precisar, que se han tomado en cuenta datos del año 2018 debido a que es la última base de datos que ha sido publicada por el INEI; datos que logran aportar, razonablemente, información relevante para el análisis y valoración de este criterio.

7.2. Incidencia de la prestación de servicios subordinados o independientes durante el despido

Cuando se invoca el daño "lucro cesante", se hace referencia directa a las ganancias netas que se venían obteniendo por la prestación de servicios subordinados. Pese a la existencia de un despido inconstitucional, dentro de la teoría de la responsabilidad civil, la víctima tiene la carga de mitigación del daño; es decir, debe procurar evitar el daño o, mínimamente, reducirlo; justamente, con la finalidad de no hacer más gravosa su situación. Asimismo, no debe perderse de vista que existe el deber de trabajar, lo cual ha sido reconocido en el artículo $22^{\circ}$ de nuestra Constitución. De igual modo, cabe reiterar que la carga de mitigación del daño, también es una manifestación del principio de buena fe contractual. Es por ello que no resulta contrario a derecho, tampoco un traslado de la responsabilidad de indemnizar del victimario hacia la víctima, ni mucho menos que esta última se pague a sí misma el daño, con el hecho de reconocer la incidencia negativa (resta) que tiene la generación de ganancias netas a través de la prestación de servicios subordinados a otro empleador - la generación de ganancias netas por trabajo independiente, durante el periodo del despido.

Debe tenerse presente lo que se busca con este resarcimiento. Se pretende reintegrar aquellas ganancias netas que se habrían logrado obtener de continuar trabajando; por lo que, si se logra generar ganancias netas de otra fuerte de trabajo subordinado, lo lógico y razonable es que esto incida en el cálculo del lucro cesante; pues, las ganancias netas de esta otra fuente de trabajo subordinado no habrían podido generarse de haber continuado trabajando para el empleador demandado. Motivo por el cual, de no reconocerse esta incidencia, estamos ante un caso de enriquecimiento sin causa o injustificado. Por lo tanto, si el empleador demandado logra demostrar que "el demandante ha percibido ingresos que no hubiese podido obtener de no haberse materializado el cese, 
estos evidentemente desvirtúan el lucro cesante en todo o en parte según sea el caso" (Ávalos Jara, 2018, p. 154). Debiendo ser precisado que lo importante es reconocer la incidencia solo de aquellas ganancias netas por trabajo subordinado que el trabajador no haya podido obtener de no materializarse el despido inconstitucional; pues, si estas ganancias perfectamente se podrían haber obtenido independientemente del despido, no tendrían por qué afectar la indemnización por lucro cesante. Del mismo modo, por ejemplo, si se tratan de servicios independientes que el demandante (víctima) habría estado generando, incluso, antes del despido inconstitucional, no sería razonable que incida negativamente en el cálculo de la indemnización por lucro cesante.

No obstante, el hecho de que el demandante (víctima) no haya prestado servicios, subordinados 0 independientes, y no haya generado ningún ingreso, no significa que sea posible deducir, por ejemplo, la remuneración mínima vital, invocando el deber de trabajar; pues, tal como ha sido reconocido en el apartado correspondiente, el hecho de no trabajar no justifica que el Estado implemente sanciones, pues nuestro propio Estado no puede garantizar el derecho al trabajo de todos sus miembros (puestos de trabajo). Por ello, si no se logra demostrar que el demandante prestó servicios subordinados o independientes, no autoriza a deducir ningún monto de la indemnización por lucro cesante.

\subsection{Periodos no imputables a las partes}

Dentro de un proceso judicial, los periodos no imputables a las partes "son aquellos que no les generan ninguna responsabilidad jurídica a los demandantes o demandados. Es decir, estos lapsos no pueden servir para atribuirle una mayor carga patrimonial al responsable" (Ávalos Jara, 2018, p. 153). Estos, son periodos que transcurren por causa no imputable a ninguna de las partes; pues, el tiempo del despido se prolonga, innecesariamente, por un hecho ajeno a la relación jurídica material y procesal. Un claro ejemplo de estos periodos es la época vacacional del Poder Judicial, la cual se lleva a cabo en el mes de febrero de todos los años; y, del mismo modo ocurre con los días o periodos en que se desarrolla una huelga de los trabajadores jurisdiccionales. En efecto, estos lapsos no pueden ser imputados a ninguna de las partes, debido a que escapa totalmente a sus actuaciones.

Lo mismo sucede actualmente, con el estado de emergencia sanitaria y cuarentena, en donde los plazos procesales, incluso, han sido suspendidos $y$, consecuentemente, es un periodo de tiempo que, por un caso fortuito, no puede ser atribuido a ninguna de las partes. En ese contexto, para lograr una valoración equitativa y razonable del resarcimiento del lucro cesante, es necesario que el juzgador excluya todos aquellos periodos inimputables a las partes; pues, generaría un perjuicio en el deudor del resarcimiento y un enriquecimiento sin causa en el acreedor del mismo.

\subsection{La carga de mitigación deldaño}

Este es un criterio o indicador que cobra relevancia al momento de establecer la carga probatoria; pues, en materia de responsabilidad civil, nuestro ordenamiento jurídico reconoce el daño cierto, como el único daño indemnizable. Por tanto, para dotar de razonabilidad y probabilidad la obtención del lucro que se deja de percibir, el demandante debería probar que ha intentado mitigar el daño, buscando obtener ingresos subordinados o independientes, pese a lo cual no ha sido posible. En consecuencia, debe tenerse en cuenta "qué hizo la víctima para minimizar el perjuicio o, en todo caso, si podía hacer algo ante ello a fin de que agudice su situación" (Ávalos Jara, 2018, p. 154); y, por tanto, en virtud de la carga de mitigación del daño y la determinación del daño cierto, el demandante debe aportar los medios probatorios que logren acreditar que sus acciones estuvieron orientadas a evitar el daño causado o, mínimamente, mitigarlo.

Asimismo, no se debe perder de vista que esta carga es una manifestación del principio de buena fe contractual, que debe ser aplicado y tomado en cuenta, incluso, desde los actos preparatorios del contrato (momento precontractual), extendiéndose hasta el momento posterior a su ejecución. Del mismo modo, como se ha estudiado y analizado anteriormente, la carga de mitigación del daño actúa también como un límite de la responsabilidad civil; con la finalidad de que los daños no se extiendan innecesariamente y tampoco se incurra en un enriquecimiento sin causa del acreedor del resarcimiento (víctima del daño). No obstante, ese sería un plano ideal del proceso laboral de indemnización por daños y perjuicios como consecuencia de un despido inconstitucional; y, además, teniendo en cuenta que no es posible aplicar sanciones específicas y directas al incumplimiento del deber de trabajar, si el demandante no aporta este tipo de medios probatorios, tampoco tendrían incidencia negativa en el cálculo del lucro cesante.

\subsection{Fórmula propuesta}

Habiendo analizado las instituciones jurídicas más relevantes para la determinación del lucro cesante en los procesos laborales de responsabilidad civil como consecuencia de un despido inconstitucional y, del 
mismo modo, habiéndose planteado los criterios o indicadores que deben tomarse en cuenta al momento de fijar el monto indemnizatorio por lucro cesante, se propone la siguiente fórmula, con la finalidad de ayudar o aportar en la labor de realizar una valoración realmente equitativa y razonable del daño:

$$
\begin{aligned}
L C=\left(\left((U R * 0.84)-\left(\sum I O * 0.84\right)\right) *(M-M N)\right) \\
\\
+\left(\frac{\left((U R * 0.84)-\left(\sum I O * 0.84\right)\right)}{30}\right. \\
*(D-D N))
\end{aligned}
$$

Donde:

$$
\begin{aligned}
\mathrm{LC}= & \text { Es el Lucro cesante } \\
\mathrm{UR}= & \text { Es la última remuneración percibida por la } \\
& \text { víctima (demandante) } \\
0.84= & \text { Es el porcentaje (84\%) que debe sacarse a } \\
& \text { los ingresos brutos, para obtener la } \\
& \text { ganancia neta } \\
\Sigma I O= & \text { Es la sumatoria de ingresos obtenidos } \\
& \text { durante el periodo del despido } \\
\mathrm{M}= & \text { Es el número de meses entre el despido y } \\
& \text { la reposición efectiva } \\
\mathrm{MN}= & \text { Es el número de meses no imputable a las } \\
& \text { partes } \\
\mathrm{D}= & \text { Es el número de días del despido, luego de } \\
\text { contabilidad los meses } & \text { Es el número de días no imputable a las } \\
\mathrm{DN}= & \text { partes }
\end{aligned}
$$

Debiendo precisarse que, en el cálculo del lucro cesante, donde se toma en consideración el periodo dejado de laborar por el demandante (trabajadorvíctima), se deben tener en cuenta además del periodo en meses, también el periodo en días; pues, el tiempo entre el despido y la reposición efectiva, casi nunca coincide con un número entero de meses.

\section{Conclusiones}

El trabajo es, al igual que un derecho, un deber de la persona en relación consigo misma y en relación con la sociedad en donde vive; pues, de aquella depende su existencia y subsistencia, el funcionamiento ordinario, el bienestar y el progreso de la comunidad. Por ello, en la actualidad, se hace necesario reivindicar esta connotación, debido a que los operadores del derecho han profundizado en el análisis del derecho al trabajo, dejando de lado su aspecto obligacional (deber).

Actualmente es incuestionable que, en nuestra realidad procesal, los jueces laborales son los competentes para conocer de los procesos de responsabilidad civil del empleador como consecuencia de despidos inconstitucionales; es decir, para conocer aquellos procesos de indemnización por daños y perjuicios como consecuencia de la inejecución de las obligaciones generadas del contrato de trabajo.

Dentro del derecho laboral y, específicamente, en las relaciones laborales que unen al trabajador y su empleador, existe consenso entre doctrinarios y juzgadores, en que la responsabilidad civil que pudiera ocasionarse dentro de estas relaciones es contractual; pues, lo que une a estas partes es un contrato de trabajo. Actualmente, aún es importante hacer esta precisión, debido a que todavía es frecuente encontrar demandas laborales sobre indemnización por daños y perjuicios como consecuencia de un despido inconstitucional, incausado o fraudulento, donde los abogados de los demandantes invocan normas de la responsabilidad civil extracontractual para sustentar sus pretensiones.

El lucro cesante, como una creación jurídica que tiene sustento en las ciencias contables y económicas, se refiere a la ganancia, utilidad o ingresos netos que deja de percibir la víctima como consecuencia del acto antijurídico ejecutado por el victimario. En cuyo caso, por definición, sería erróneo pensar, y más aún, establecer que el lucro cesante incluye todos los ingresos que la víctima pudo haber obtenido sin la incidencia de ningún costo; pues, toda actividad económica genera un costo, en el cual se incurre, justamente, para obtener la utilidad o ganancias que se buscan a través de dicha actividad. Lo que implica, en efecto, que en materia de responsabilidad civil en el ámbito laboral (por despido inconstitucional), el lucro cesante no puede ser equiparado a los ingresos brutos que percibiría el trabajador en el supuesto de que la relación laboral seguiría vigente; sino, el lucro cesante en realidad expresa aquella utilidad o ganancia (neta) que el trabajador deja de percibir; lo cual, como ya se expresó, no es lo mismo.

Es importante tener en cuenta que la responsabilidad civil (contractual o extracontractual) tiene límites; pues, tal como muchos autores lo han reconocido, incluso la misma jurisprudencia así lo ha establecido, no todos los daños son indemnizables. Por lo que, la mitigación del daño como una carga de la víctima del mismo, actúa no solo como una manifestación del principio de buena fe contractual; sino, sobre todo, como un límite de la responsabilidad civil; o, dicho de otro modo, como un límite de la cuantificación de la indemnización; debido a que, esta mitigación del daño significará, en definitiva, un criterio para exonerar al victimario del pago del resarcimiento o, mínimamente, para reducirlo; justamente, porque el hecho de no permitir que el victimario asuma o pague una indemnización, representa también uno de los criterios basilares de los daños patrimoniales, el cual es que la indemnización o 
resarcimiento no puede implicar un enriquecimiento del damnificado.

En la Casación Laboral 10956-2017-TACNA, el monto que reconoce la Corte Suprema como lucro cesante está lejos de representar una cuantificación equitativa y razonable; pues, ha dejado de lado lo más básico del significado de este tipo de daño: utilidad o renta neta. Además de lo cual, la Corte Suprema ha negado la incidencia de que la víctima haya obtenido ingresos mensuales a través de otro empleador, los cuales no habría podido obtener de no haberse configurado el hecho dañoso; con lo que, la víctima ha actuado de acuerdo a la carga de mitigación del daño. Esto significa, contrariamente a lo reconocido por la Corte Suprema, que se ha establecido un monto indemnizatorio por lucro cesante que es irrazonable y arbitrario, y desconoce los criterios establecidos por nuestro ordenamiento jurídico en materia de responsabilidad civil contractual, detallados en el Código Civil. Por lo tanto, la fórmula establecida por la Corte Suprema, debe rechazarse, por no ser coherente con la institución jurídica de la responsabilidad civil y, específicamente, con el lucro cesante como un tipo de daño indemnizable.

Resulta necesario proponer un método con el que se logre determinar el quantum indemnizatorio por lucro cesante en los procesos laborales de responsabilidad civil como consecuencia de un despido inconstitucional y que, además, represente una valoración equitativa y razonable del daño. Por lo que, se plantea, a manera de propuesta, la siguiente fórmula:

$$
\begin{aligned}
L C=\left(\left((U R * 0.84)-\left(\sum I O * 0.84\right)\right) *(M-M N)\right) \\
\\
+\left(\frac{\left((U R * 0.84)-\left(\sum I O * 0.84\right)\right)}{30}\right. \\
*(D-D N))
\end{aligned}
$$

\section{Bibliografía}

Academia de Inversión. (29 de septiembre de 2016). El coste de oportunidad: Concepto, ejemplose importancia en la toma de decisiones financieras (y no financieras). Obtenido de https://www.academiadeinversion.com/costede-oportunidad-concepto-ejemplos/

Alpa, G. (2016). La responsabilidad civil. Parte general (Vol. 2). (C. Moreno More, Trad.) Lima: Editora y Distribuidora Ediciones Legales.
Alpa, G. (2016). La responsabilidad civil. Parte general (Vol. 1). (C. Moreno More, Trad.) Lima: Editora y Distribuidora Ediciones Legales.

Arim, R. (2012). Introducción a la económía. Escasez y racionalidad. Obtenido de https://www.fing.edu.uy/catedras/economia/te orico/Ficha1_Micro_2015.pdf

Ávalos Jara, O. (diciembre de 2018). Límites razonables al uso desmedido del lucro cesante en materia laboral para los casos de despidos incausados y fraudulentos. Soluciones Laborales(132), 143156.

Barreto, M., \& Sarmiento, L. (1997). Constitución política de Colombia, comentada por la comisión colombiana de juristas. De los derechos, las garantías y los deberes. Bogotá: ImpreandesPresencia.

Blancas Bustamante, C. (2003). El derecho al trabajo en la futura constitución. Revista $\operatorname{PUCP}(56), 795$ $824 . \quad$ Obtenido de http://revistas.pucp.edu.pe/index.php/derechop ucp/article/view/10597/11069

Constitución Española. (1978). Obtenido de http://www.senado.es/web/conocersenado/nor mas/constitucion/detalleconstitucioncompleta/i ndex.html\#t1c2s2

Constitución Política de Colombia. (1991). Obtenido de https://www.corteconstitucional.gov.co/inicio/C onstitucion\%20politica\%20de\%20Colombia.pdf

De Trazegnies, F. (1990). La responsabilidad extracontractual (Cuarta ed., Vol. I). Lima: Fondo Editorial de la PUCP.

Del col, J. (2007). Diccionario auxiliar español-latino para el uso moderno del latín. Buenos Aires: Instituto Superior Juan XXIII. Obtenido de http://www.colegiosanjose.net/latin/diccionario s/diccionario_latin.pdf

Espinoza Espinoza, J. (2016). Derecho de la responsabilidad civil (Octava ed.). Lima: Pacífico Editores.

Infante Caffi, H. (s.f.). El factor de atribución en la responsabilidad civil contratual por el hecho ajeno. Obtenido de https://derechoyhumanidades.uchile.cl/index.ph p/RDH/article/download/25775/27102/

Instituto Nacional de Estadística e Informática. (2018). Ingreso promedio mensual proveniente del trabajo, según ámbito geográfico. Obtenido de INEI:

http://m.inei.gob.pe/media/MenuRecursivo/indi ces_tematicos/ing-cuad-1.xlsx

Instituto Nacional de Estadística e Informática. (2019). Evolución de la probreza monetaria 2007-2018. 
Informe Técnico, INEI, Lima. Obtenido de https://www.inei.gob.pe/media/MenuRecursivo /publicaciones_digitales/Est/Lib1646/libro.pdf

León Hilario, L. (2017). La responsabilidad civil. Líneas fundamentales y nuevas perspectivas (Tercera ed.). Lima: Pacífico Editores.

León XIII. (1891). Encíclica Rerum Novarum. Roma. Obtenido de http://www.vatican.va/content/leoxiii/es/encyclicals/documents/hf_Ixiii_enc_15051891_rerum-novarum.html

León XIII. (1960). Rerum Novarum. Sobre la cuestión obrera y radiomensaje de S.S. Pío XII en el cincuentenario de la encíclica. Santiago de Chile: Paulinas. Obtenido de https://www.bcn.cl/obtienearchivo?id=docume ntos/10221.1/46080/1/208314.pdf

Menéndez Álvarez, D. (1980). Concepto de ganancia realizada. Tesis de doctorado: Universidad de Buenos Aires. Obtenido de http://bibliotecadigital.econ.uba.ar/download/te sis/1501-1082_MenendezAlvarezDO.pdf

Ortega Piana, M. (2015). Artículo 1327. Liberación del resarcimiento. En Tratado de responsabilidad civil contractual y extracontractual (Vol. I Responsabilidad Contractual, págs. 273-281). Lima: Pacífico Editores.

Pérez Velázquez, J. (enero de 2015). La carga de evitar o mitigar el daño derivado del incumplimiento del contrato. InDret - revista para el análisis del derecho, 2-63. Obtenido de https://indret.com/wpcontent/themes/indret/pdf/1112_es.pdf

Quispe Montesinos, C. (noviembre de 2019). El lucro cesante en los despidos incausados y fraudulentos. Soluciones Laborales(143), 128139.

Taboada Córdova, L. (2003). Elementos de la responsabilidad civil (Segunda ed.). Lima: Grijley.

Toyama Miyagusuku, J. (2005). Artículo 22. En La constitución comentada (Vol. I). Lima: Gaceta Jurídica.

Ugarte Mostajo, D. (2018). La mitigación de daños en la responsabilidad por incumplimiento contractual: breve análisis comparado en el derecho civil de Argentina y Perú. Revista de la Facultad de Derecho de la PUCP(80), 120-159. Obtenido de http://www.scielo.org.pe/pdf/derecho/n80/a04 n80.pdf

Casación, 2677-2012-Lima (Corte Suprema 12 de noviembre de 2013).

Casación, 2097-2013-Lima (Corte Suprema 11 de marzo de 2014).
Casación, 7589-2014-Cañete (Corte Suprema 5 de noviembre de 2015). Obtenido de https://static.legis.pe/wpcontent/uploads/2018/07/Casaci\%C3\%B3n7589-2014-Ca\%C3\%B1ete-Legis.pe .pdf

Casación Laboral, 4977-2015-Callao (Corte Suprema 21 de enero de 2016).

Casación Laboral, 7625-2016-Callao (Corte Suprema 7 de diciembre de 2016).

Casación Laboral, 2996-2017-Cusco (Corte Suprema 27 de junio de 2019). Obtenido de https://prcp.com.pe/wpcontent/uploads/2019/07/CAS-2996-2017Cusco-Lucro-cesante-no-debe-incluirremuneraciones-dejadas-de-percibir-ybeneficios-sociales.pdf

Casación Laboral, 10956-2017-Tacna (Corte Suprema 15 de febrero de 2020).

Pleno Jurisdiccional Laboral (Tarapoto 5-8 de julio de 2000). Obtenido de https://www.pj.gob.pe/wps/wcm/connect/260e b00043eb77ff9317d34684c6236a/Acuerdo_Ple no Laboral+2000 220408.pdf?MOD=AJPERES\& CACHEID=260eb00043eb77ff9317d34684c6236

Pleno Jurisdiccional Nacional Laboral (Lima 27-28 de junio de 2008). Obtenido de http://historico.pj.gob.pe/CorteSuprema/cij/doc umentos/CONCLUSIONES_DEL_PLENO_JURISDIC CIONAL LABORAL NACIONAL.pdf

Pleno Jurisdiccional Nacional Laboral y Procesal Laboral (Tacna 23-24 de mayo de 2019). Obtenido de https://static.legis.pe/wpcontent/uploads/2019/11/Conclusiones-PlenoNacional-Laboral-2019-LP.pdf

STC 1124-2001-AA/TC (Tribunal Constitucional 11 de julio de 2002). Obtenido de https://www.tc.gob.pe/jurisprudencia/2002/011 24-2001-AA.html

STC 008-2015-PI/TC (Tribunal Constitucional 12 de agosto de 2005). Obtenido de https://www.tc.gob.pe/jurisprudencia/2005//00 008-2005-Al.html

STC 728-2008-PHC/TC (Tribunal Constitucional 13 de octubre de 2008). Obtenido de https://www.tc.gob.pe/jurisprudencia/2008/007 28-2008-HC.pdf

STC 1647-2013-PA/TC (Tribunal Constitucional 3 de noviembre de 2015). Obtenido de https://www.tc.gob.pe/jurisprudencia/2017/016 47-2013-AA.pdf

$\checkmark$ Pleno Jurisdiccional Supremo en Materia Laboral y Previsional (Lima 19 de octubre de 2016). Obtenido 
https://www.pj.gob.pe/wps/wcm/connect/11ce d88042dde0c2ad14ff7c7547a143/Acta.pdf?MO $\mathrm{D}=\mathrm{AJPERES} \& C A C H E I D=11 \mathrm{ced} 88042 \mathrm{dde} 0 \mathrm{c} 2 \mathrm{ad} 14 \mathrm{f}$ $\underline{\text { f7c7547a143 }}$ 